\title{
A WORD ABOUT THE COVER
}

The photograph on the cover was taken by Menachem Kahana, an Israeli photographer who was given unprecedented access to the Israeli Haredi community. His photographs were later published in a volume called Haredim (Tel Aviv, Israel: Eretz Israel Museum, 2009).

This photograph was taken from behind the Hasidic Rebbe of Belz as he was conducting a ceremonial meal known as a tisch. Next to the back of the Rebbe is his trusted assistant, known as a shamish. Flanked on both sides are hundreds of Hasidim watching carefully at the Rebbe's moves and utterances.

But that's not why I love the photograph.

Underneath the table where the Rebbe sits is a lone child, patiently and quietly hiding and listening to the Rebbe. If you look at the picture quickly, you may not even notice the child underneath the table. I like to think that each section of the photograph depicts a different element of the Jewish community. You have your leader, the Rebbe. Each leader has his righthand men, the proverbial "number two." And of course, the followers who anxiously wait for direction. But the person that interests me most is the one who is not at the table. The child hiding underneath. The people on the periphery. Such people inspire me, and I think this picture aptly portrays many of the feelings this book will hopefully describe. It's not enough to connect with leaders and their loyalists-you also need to check who is not at the table. 


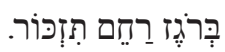

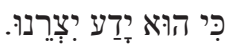

סדר תחנון-

In wrath, remember mercy.

For he knows our nature.

-Tahanun 